\title{
Study on the Legal Construction of Rural Social Governance in Xinjiang Aksu Prefecture
}

\author{
Ma Wentao, Ma Shaowei \\ College of economics and management Tarim University Alar Xinjiang 843300, China
}

Keywords: Xinjiang Rural Society, Rule of Law, Construction.

\begin{abstract}
Because of many factors, the construction of the rule of law in Xinjiang is very different from other provinces, the rural society in Xinjiang has a certain particularity, and the construction of the rule of law should also be based on the actual situation in Xinjiang and take corresponding governance measures. Therefore, the rule of law in rural social governance must follow the rule of law thinking, adhere to system governance, govern by law with comprehensive control, and perform source management under the basic strategy of running the country according to law. To further strengthen the moral nourishing the rule of law, strengthen grassroots organizations, and strengthen the comprehensive management of public security.
\end{abstract}

\section{Introduction}

Promoting the legalization of rural areas in Xinjiang is a major manifestation of the ability to govern the country, and it is also an important way of rural social governance in Xinjiang. How to promote the rule of law construction and rapid development of rural social governance has become an urgent problem in Xinjiang, the author thinks that the rule of law in rural social governance must follow the rule of law thinking, adhere to system governance, govern by law with comprehensive control, and perform source management under the basic strategy of running the country according to law, and bring rural social governance into the orbit of the rule of law.

\section{Current Situation of Legal Construction of Rural Society in Xinjiang}

Rigid Governance and Lack of Flexibility.In the current practice of rural social governance in Xinjiang, a lot of local governance is too rigid, ignoring flexible governance and lack of flexibility. Some leading cadres at the grassroots level enjoy a stable and rigid operation mechanism, they are customary to mediate social contradictions and resolve social conflicts in a static social fixed framework, it is hoped that all the unstable factors will be nipped in the bud by administrative means and outdated management methods. When strange phenomena occur that "the old method doesn't work, the hard trick won't work, and the soft approach couldn't help”, the the disadvantages of traditional management revealed. Thus the potential risks around could not be found and greater risk would be breed.

Ignore the Construction of Prevention Mechanism.Many leading cadres at the grass-roots level tend to ignore the construction of prevention systems, they unilaterally thought that : "No conflict means social stability, no petition, riot means work in place", which confined to the incident before the governance of small ideas among them. Once the risks or contradictions are accumulated and broke out, under the "stability overrides all" requirements, some leading cadres at the grassroots level tend to take no account of their costs, making prompt military decision, solving problems only at a speed, without seeking the root of the problem, it is likely to lead to more social contradictions and risks in rural areas of Xinjiang, which leads to big criminal cases, even mass incidents, and goes out of hand.

Governance Lacking A Certain Initiative.The idea that the incident was governed only because of the lack of initiative in the governance of many rural grassroots cadres in Xinjiang, and that governance is in a passive role. Farmers are the main body of rural social governance, and the 
main channel of the actual orderly participation is narrow. Grassroots governments tend to put themselves and farmers simply in the two roles of manager and the governed, ignoring equal consultation, dialogue and demands expression, thus the peasants do not understand the management, and the managers think that the peasants' demands are nonsense. In addition, there is no orderly development, diversified society, autonomous organizations, a considerable number of peasants are basically in an unorganized state and are difficult to participate in the governance of rural society.

\section{Thoughts on Legal Construction of Rural Society in Xinjiang}

Strengthening the Propaganda of Law and Morality in Rural Areas of Xinjiang.First of all, to strengthen the rule of law publicity and education, establish a sense of rule of law in rural areas. In terms of specific publicity, seize the contemporary Xinjiang large-scale holidays, holiday market, commemorative activities and other opportunities, through legal advice, legal lecture, caution education, knowledge contest, theatrical performances, law pictures exhibition, mobile court, movies go to the countryside, mobile phones, networks and other forms and means loved by the masses of farmers, seize typical cases for in-depth explanation, and enhance publicity targeted and effectiveness. For publicity contents, closely related to the party and state policies and policies related to rural areas and rural reform, development and stability of the reality, vigorously carry out the publicity and education of the rule of law at the core of the Constitution, further strengthen the people's awareness of the Constitution and the law, and establish and maintain the authority of the Constitution and the dignity of the law; vigorously carry out the agricultural production, life as the focus of the laws and regulations publicity, further maintain and improve the economic and social order in the rural areas, actively guide the broad masses of peasants to act in accordance with the law and safeguard their rights according to law, further consolidate the basis of democracy and rule of law in rural areas in Xinjiang. On the publicity target, seize the key targets and carry out different forms of legal publicity for different objects in different rural areas in Xinjiang. For example, the focus of legal education should be based on the village two committees team members, members of the village collective economic organizations responsible person and young people. Let them play a leading role in the observance of the law and the strict handling of the law. Especially for rural teenagers, strengthen the publicity and education of the rule of law, through the rural primary and secondary schools equipped with the principle of vice president of the rule of law, counselors and other ways, so that the rule of law knowledge get into the campus and into classrooms.

Secondly,carry out legal advisory services, and effectively answer questions for rural objects. In accordance with the actual needs of rural development and the masses of peasants, the rural lawyers should be organized and conducted at the right time, help rural people who really need legal aid, so as to realize a law to ask, a place to inquire, especially to help the farmers with various kengnonghainong and trampling damage behavior of farmers' democratic rights struggle, especially protecting the farmers' legitimate rights and interests of vulnerable groups. Where conditions permit, I can hire legal consultants to provide legal advice and assistance for major decisions and village affairs in a timely manner, handling the economic and social affairs of the region in accordance with the law, and correctly handling the contradictions among the rural people in the new period. Focus on exploring the system construction of the circuit court, and find the starting point for the judicial people. Explore boldly and drive the court to the countryside, community form, on some simple cases in situ trial, extensive patrol court activities, directly facing the masses, which not only saves the party's time, energy and cost of litigation, but also gets the good results of the case and decides the good social effects

Finally, strengthen ethical propaganda and work together in accordance with morality and the rule of law. While promoting the construction of the rule of law unswervingly, we should strengthen the function of moral education, and efforts should be made to protect and tap the rural traditional natural resources and excellent human resources, make full use of rich and colorful folk ethics and local cultural characteristics, and promote the reform of folk ideas. Through extensive publicity, the socialist core values are widely known; through the selection of the best farmers and other forms, 
the moral construction is integrated into the rich social practice. Vigorously carry forward the spirit of courageous and courageous, the establishment of courageous reward mechanism, from a spiritual, material, high-profile recognition, publicity, the lifting of the courageous people's worries.

Strengthen the Construction of Rural Grassroots Organizations in Xinjiang.First of all, establish and improve the rural grassroots organizations in the rule of law in Xinjiang, raise the level of rural rule of law management. Sound and perfect to the grassroots party organizations as the core, the villagers congress and other mass organizations as a platform to rural economic organizations and comprehensive management organizations as a skeleton covering the entire rural and farmer management service network. In particular, it is necessary to set up a meeting of villagers' representatives, a democratic financial management group, and a mass autonomous organization, such as the red and white Council, which are important to the interests of the villagers. For example, the scope of the "one case, one discussion" of the village, the use of proceeds from the collective economy of the village, the compensation for collective land expropriation, the land contract, the use of homestead and the scheme of the collective economy project, all must be referred to the villagers' representative meeting or the villagers' meeting according to the opinions of the majority. Reduce and prevent the abuse of public power, so that power in the sun standardized operation. For inaction, slow action, and confusion of village cadres, supervise and control the rule of law management organizations.

Secondly, to strengthen the Xinjiang rural village development, improve farmers' awareness of the rule of law. As a kind of civil standard based on the willingness of the villagers, the village rules and regulations are not only the role of improving the level of rural governance by means of moral education, but also have the effect of resolving contradictions, promoting harmony and maintaining social stability in rural areas. It is worth noting that the society is constantly developing, the village rules and regulations also need to advance with the times, need to abandon the individual dross composition, but also can not be contrary to the existing national laws and regulations. To take the opportunity to revise the village rules and regulations, increase education, do publicity, supervision, promotion, mobilize more active participation of the masses, to reach a consensus. Especially in relation to the rights and interests of the peasant masses, through the effective promotion of the village rules and regulations, to achieve well-documented work, orderly and effective implementation.

Finally, improve the system of national autonomy in rural areas of Xinjiang. Encourage and explore the effective forms of villager autonomy under different circumstances, and respect the status of the peasants as the main body, integrate the democratic election, democratic decisionmaking, democratic management, democratic supervision and village affairs and financial disclosure into the construction of rural democratic politics. Conduct full implementation of the villagers' consultation system, make common research on village matters, in particular, agricultural subsidies, new cooperative medical care and other matters of money and road construction and other major sensitive matters, one by one to study the details of the program, brainstorming, focus on people's wisdom, so that the majority of farmers directly or indirectly involved in village affairs management, improve the scientific decision-making, to avoid mistakes. Efforts should be made to promote the publicity of village affairs, focusing on the issues that are most concerned with the interests of the masses and closely related to the interests of the masses, make specific provisions on public matters, public time, public place, acceptance of opinions, examination methods, etc. Further improve and implement the detailed rules for the implementation of village affairs and the administration of democracy, so that the supervision of the masses will be extended to the whole process of decision-making and implementation of village affairs.

Strengthening the Comprehensive Management of Public Order in Xinjiang Rural Areas and Maintaining Social Stability.First of all, the establishment of rural grassroots contradictions and disputes in Xinjiang investigation and resolution mechanism. Promote the rule of law in rural social governance, it is necessary to solve the masses to reflect the strong public security issues, but also the implementation of the root causes of the measures. To be good at discovering the tendency of the signs and processing belt. Every six months, the organization should carry out an 
investigation of contradictions among the people and all kinds of unstable factors, work plans and implement preventive measures. Actively and correctly guide the masses, mediate various conflicts and disputes in a timely manner, and focus on investigation and mediation, which may lead to mass incidents and civil disputes that may translate into criminal cases. Give full play to the police station, justice, comprehensive management office and the people's mediation organization role, further establish and improve the working mechanism for investigation and mediation of contradictions and disputes, and combine judicial mediation with civil mediation and administrative mediation in a close manner. To promote and copy the "Fengqiao Experience" that "mobilize and rely on the masses and solve problems on the spot", try to eliminate the contradictions in the bud and dissolve them at the grassroots level.

Secondly, strengthen the security control and control of key parts and targets. In rural areas of Xinjiang such as financial room, warehouse, canteen, teahouse, cattle, transformers and other key targets and the boundary, mountains, reservoirs, roads, urban fringe, fishing, entertainment, religious sites and other key parts, we should strictly implement the regular patrol and duty system, and strengthen prevention and management. Strengthen the management of the floating population and key personnel. Adhere to the "household registration management as the basis, security management as the center, labor management as the focus, and other management matching" principle, the implementation of urban management of rural population. For the floating population, especially migrant workers, domicile should strictly register, contact at regular intervals, for places where migrant workers are relatively concentrated, establish an organization that facilitates unified management, and appoint a designated lead person.

Finally, take severe measures against all acts of lawlessness, adopt more resolute and effective measures, crack down on all kinds of illegal and criminal activities. For villages, sections and parts with disorderly public order and intense mass reactions, especially in small towns in rural area, fishing area, forest, urban and county border area, the political and legal departments should take the villages and towns as the operational areas, according to local conditions, seize the tendentious policing problem, organize strong special team, carry out special rectification and special treatment, strike against a group of tyrants, trolls, fishing despot, electric tyrant and other criminals and bring evil gangs arrogance, strive to crack down on the permanent Xinjiang rural areas.

\section{References}

[1] Guo Shisong. Study on the Legalization of Rural Social Governance [J].Journal of Hubei Institute of Socialism 2015 (03)

[2] Guo Shisong. Study on Promoting the Legalization of Rural Social Governance [J]. China Development, 2015 (03)

[3] Hu Yongping. Analysis of Obstacle Factors in the Construction of Rural Legal System in Xinjiang [J]. Journal of Shangqiu Vocational and Technical College, 2009 (03)

[4] Guo Yu Junwei. Study on the Construction of Rule of Law in Rural Areas of Shache County in Xinjiang [D]. China University of Geosciences (Beijing), 2016 